\title{
Negotiating Universalism and Cultural Relativism in Peace and Development Studies
}

\author{
Paul Bukuluki \\ School of Social Sciences, College of Humanities and Social Sciences, \\ Makerere University, Kampala, Uganda \\ Tel: +256 772462100 \\ E-mail address: pbukuluki@gmail.com \\ "The boundaries between universalism and cultural relativism are meeting \\ points and opportunities for exchange and growth rather than areas of separation"
}

\begin{abstract}
Culture is an indispensable factor for both sustainable development and lasting peace since it forms the fabric for people's mutual respect and co-existence. The paper argues for the need to constantly negotiate between universalism and cultural relativism in peace and development studies. It argues that any attempt to radically lean towards either universalism or cultural relativism without providing room for a conversation between the two would either lead to narrowly focusing on the local context without taking into account the global discourses or following the global discourses that may be far removed from the local context to make any sense to the affected people. Without sounding idealistic, the paper argues for the need to nurture and create space for hybridity that emerges out of the negotiation between cultures rather than suffocate it in favor of the local context or universals. The paper argues for adoption of concepts such as cosmopolitan localism that take into account global discourses but also maintain a strong focus on the context in which people experience conflict, peace and development as perceived and experienced by them.
\end{abstract}

Keywords: Culture; Universalism; Cultural Relativism; Hybridity; Conflict; Peace; Development

\section{INTRODUCTION}

In cogitating about universalism and relativism, there is need to answer some fundamental questions? Is there a pure culture? Or is there an impure culture? Is there a culture that is separable and separated from others? Are there convergences between those who claim to be Universalists and those who claim to be cultural relativists? Answers to these questions may help us to reflect more critically on the notions of universalism and cultural relativism. But before we get deeper into these debates, it is instructive to reflect on the concept of culture. There are various definitions of culture. However, I am fascinated by the definition by Helman $(2007,2)$. In Helman's conceptualization,

"Culture is a set of guidelines (both explicit and implicit) that individuals inherit as members of a particular society, and that tell them how to view the world, and how to 
experience it emotionally, and how to behave in it in relation to other people, to supernatural forces or gods and to the natural environment".

He adds that "it also provides them with ways to transmit these guidelines to the next generation - by use of symbols, language, art and rituals". In his conceptualization of culture, Cecil refers to the work of American Anthropologist, Edward Hall who conceptualized culture to be at three levels; tertiary, secondary and primary levels of culture. The tertiary level of culture refers to the explicit manifest aspects of culture that are visible to the outsider like social rituals, traditional dress, national cuisine and festive occasions. The secondary level of culture refers to a "series of underlying assumptions and rules known to the members of a cultural group but rarely shared with outsiders" while the primary level of culture represents the deepest level of culture "in which the rules are known to all, obeyed by all, but seldom if ever stated" (Helman, 2007, 2-3).

What is not clear are the levels of culture within which cultural relativists or those who believe in Universalism are operating from. We know that both relativism and universalism are cultural phenomenon and they are social constructions. In this respect, I would like to cite Von Glasersfeld (1991:) who argues that "we cannot know such a thing as an independent, objective world that stands apart from our experience of it... knowledge is not a particular kind of product that exists independent of the knower, but an activity or process". The constructivist approach puts emphasis "on the world of experience as it is lived, felt and undergone by social actors. In his antithesis of positivism, Glasersfeld (1989: 162) argues that "knowledge is a self-organised cognitive process of the human brain; it is not aimed at a 'true' image of the 'real' world but at a viable organisation of the world as it is experienced". I am fascinated by Glasersfeld's arguments that lean towards what has been termed as "Radical Constructivism". Glasersfeld (1989: 162) makes two crucial points that are important for making a case for negotiation between cultural relativism and universalism:

"(a) Knowledge is not passively received but actively built up by the cognizing subject; (b) the function of cognition is adaptive and serves the organization of the experiential world, not the discovery of ontological reality."

This implies that those who subscribe to universalism as well as those who subscribe to cultural relativism are doing it out of their subjective experience. This reminds me of White (1959) who noted that "between man and nature hung the veil of culture and he could see nothing save through this medium...meanings and values that lay beyond senses" (White 1959). In other words, both 'Universalists and cultural relativists are using culture as the medium through which they can perceive, understand and interpret things around them. We are also reminded by several anthropologists that cultural constructions and meanings are not static; they keep changing i.e. meanings are shifting, uncertain and unstable.

However, at a given time, space and situation culture serves as a lens through which people see, perceive, interpret and attach meaning to things. Quintessentially, the positions and experiences of those who believe in relativism as well as those who subscribe to universalism are uncertain, unstable and highly dynamic. Similarly, if we accept that Universalism and cultural relativism are cultural constructions, then the questions below should be interesting especially for radical cultural relativists:

- Is local culture united, pure and homogeneous?

- Is local culture is an uncontaminated space (migrants, colonizers, traders, missionaries)?

- Is there syncreticism within the 'local culture'? 
- Can local culture be viewed as having multiple internal and external connections?

In trying to understand complex issues like culture and identity, there is need to bear in mind that in quite a number of cases, the differences between cultures are magnified in order to create the distinction between "we" and "they". "We" - the "universalists" and "they" - the "cultural relativists'. In her analysis of the notions of "us vs. them", Anna Lübbe noted that:

"Ethno-political conflicts tend to escalate to a point where it seems impossible to acknowledge the "other" without giving up oneself. Externalizing everything that is weak, bad, and inhumane onto "them" enhances a feeling of togetherness, strength, and heroism within "us"... the division into a heroic self and a worthless "other" as an entrapment; it shows its allurement as well as its hopelessness once established... One can perhaps generalize and state that the more undifferentiated and the less human the members of the other group are perceived to be, the more inhumanly they will be treated by those who have that perception, and perceive themselves as the good." (Lübbe, 2009, 2-3).

This argument demonstrates how radical and fundamentalist parties involved in highly escalated conflicts involving struggle for identity can blatantly become lost in their denial of reality. This seems to re-enforce and sustain the perception that the other group are the bad ones, and that destroying "them" is "a right and necessary act of the good ones" (ibid). This seems to rhyme squarely with radical universalism and radical cultural relativism. These two "believers" seem to see nothing good about the other and tend to deny any room for negotiation and conversation.

An anthropological reading of the literature in cross-cultural studies reveals that universalists have a strong bias toward discovering cross-cultural similarities and universals (Kleinman, 1988). For example, much of cross-cultural biomedical research has been initiated from a wish to demonstrate that health conditions are universal and respond the same way to treatment: "it occurs in all societies, and it can be detected if standardized diagnostic techniques are applied". This is done without giving adequate consideration to the social and historical context (Kleinman's, 1988). "Diagnosis then becomes reductionist, the semiotic interpretation of the signs of disease as an entity or object out of the blooming, buzzing confusion of illness symptoms" (ibid). Therefore the tendency is to leave out the experience of suffering out of the assessment of disease in the interest of teasing out universals. We increasingly see over emphasis of similarities and de-emphasizing peculiarities in the evidence. Drawing from Arthur Kleinman's arguments, the question then, is how can we develop methodologies that take into account the universals but also give adequate attention to differences?

Within this discourse, Olaniyan cited by Norval $(1997,7)$ identifies two distinct discourses in the debates on cultural identity and difference: The profane and the sacred. The sacred relates more to the moral notions of justice which has a strong inclination towards dualism and the absolute truth. Culture and identity of any system is conceptualized in terms of a "given totality, separated and separable from other cultures with exactness of a puritanical slide rule". In other words, elements of a culture are taken to be non-contradictory and nonantagonistic. This implies that the difference from other cultures is conceived as "absolute, closed and impenetrable" (Norval, 1997, 7-8). This is similar to the argument made by Wolfgang Sachs that: 
"...For centuries, universalism has been at war with diversity. Science, the state and the market have dominated this campaign... Science, the state and the market are based on a system of knowledge about man, society and nature that claims validity everywhere and for everybody..." (Sachs, 2006, 219).

This further augurs well with Wolfgang Sachs' notion of "space against place". He argues that universalistic cultures do not subscribe to any place; they are space rather than place centered. He postulates that their mental style is not linked to any place but "rests instead on the concept of space" (Sachs, 2006, 219). He aptly states that "universalists aspirations are space centered while localists world views are mainly place-centered" (ibid). This distinction demonstrates the tension between the protagonists of cultural relativism and universalism in peace and development studies.

Contrary to universalism, cultural relativism assumes that there is no culture whose values and customs dominate in a moral sense (Lund, 1999, 4). Implied therefore is that any culture deserves to consider itself as discrete and more so exclusive. In cultural relativism, the premise is that "cultures are connected to particular places, with their own particular peoples, memories and cosmologies" (Sachs, 2006, 219). The question is how; cultural-bound is the idea of cultural relativism itself. The claim that all cultures should enjoy equal rights is a universal ethics principle per excellence (Lund, 1999, 4). This may imply that cultural relativists do not fully reject universal ethics as they claim to do. At a general level, Lund $(1999,4)$ calls for "the universalist to recognize the relativist element in their claim and conversely that cultural relativists recognise the universal element in theirs".

The discourse on universalism and cultural relativism seems to provide two choices. One that seeks to replace diversity with sameness and the other that assumes that plurality is here to stay and therefore, declares plurality to be good and sets to make the best of it in order to make human co-habitation better (Lund, 1999, 8). Jack Donnelly in his article "cultural relativism and universal human rights, noted that cultural relativism is a doctrine that holds that such variations are exempt from legitimate criticism by outsiders, which is mostly supported by the notions of communal autonomy and self-determination. He adds that radical cultural relativism would hold that culture is sole source of the validity of moral right or rule. Ikuenobe (2006), in his comments on cultural relativism from a philosophical perspective noted that; "cultures and tradition are so diverse and different that it would be methodologically and philosophically unreasonable to make a fair generalization about dominant or common philosophical themes in [African] cultures" (also see Gbadegesin and Enilyan, 1998, 175; Gyeke, 1995, 129). Similarly, quite a number of [African] scholars have argued against the idea of generalizing about all 'African' Societies or cultures. Those who take this position argue that each culture must be treated individually in its own right. It is argued that this requires "analyzing the philosophical and conceptual issues in the thought and belief systems of each culture in turn" (see Gbadegesin, 1998, 175).

For example, in order to steer clear of treating all African cultures and traditions as a monolith, some African philosophers try to find different thoughts in each different African culture" (Ayoade, 1984; Gyekye, 1978). Instead of focusing on similarities among African cultures, they prefer to conceptualize them as discrete and context specific (Kuenobe, 2006). Yet, radical universalism would hold that culture is irrelevant to the validity of moral rights and rules which are universally valid. This could be a first-step towards the 'work of retrieval' as precisely put by Taylor (1991, 72 cited in Lund, 1999, 5). Instead of dismissing one view and endorsing another, we ought to investigate the relation between different practices and their ideals. 
The profane discourse presented by Norval helps to demonstrate this argument. The profane discourse "insists on the madness of culture and the eventedness of every identity. Culture is conceived as a complicated articulation of mutually contradictory and antagonistic elements" Norval (1997, 7-8). Norval adds that cultural identity from this perspective cannot be seen as closed and positive but it "exists as fragile and vulnerable - as a hybrid and non pure" (ibid). Profane is synonymous with non purity and/or hybridity of identity of any culture (Bukuluki, 2010). Thus when two cultures meet, they do not meet and mix as pure cultures. I therefore argue that universalism and cultural relativism meet, they meet as impure cultures and identities. They are impure, mad and contaminated. Any attempts to magnify their differences tend towards utopia.

Universalism is not pure, it has mutually contradictory and antagonistic elements and so is cultural relativism. Hybridity and/or hybridism therefore create(s) room for conversation and negotiation (Bukuluki, 2010) between universalism and cultural relativism but not enough has been done to make use of this space.

Using the systems theory, I argue that both universalism and cultural relativism are part of the whole and the whole is bigger than the sum of its parts. Chaos theory and systems theory argue for an aesthetic sense: instead of resisting life's uncertainties, we should creatively embrace them not as controllers but as creative participators (Briggs and Peat, 1999). In effect “...it's not that reality can't be accurately described, but old ways of thinking don't always provide the right tools." ${ }^{\prime}$ From a theoretical perspective, chaos theory is congruous with the postmodern paradigm, which questions deterministic positivism as it acknowledges the complexity and diversity of experience (Levy, 1994, 169). Chaos theory underlines the need to open ourselves to creative dimensions that make our lives deeper (Bukuluki, 2010).

As Levy argues, "only by becoming multi-dimensional can we operate in civilization's third millennium ... given the dynamic set of circumstances and needs, for which linear thinking cannot always generate a solution" (Levy, 1994, 169). Both universalism and cultural relativism perspectives are incomplete as explanatory models of peace and development in the daily lives of affected by conflict, poverty and uncertainties. They need to creatively complement each other and deal with the inherent and antagonistic elements. I find the concept of hybridity and the chaos/systems theory useful in moving away from getting stuck to one worldview of peace and instead move towards a creatively negotiated discourse between universalism and cultural relativism.

The relational cultural theory (RCT) inspired by the works of Miller (1976) also has a lot to contribute to the debate of interactions between cultural relativism and universalism in peace and development perspectives. It conceptualises boundaries between systems as porous; "places of meeting, exchange and maximal growth" rather than "walls of protection against others" (Jordan and Hartling, 2002, 8). According to the RCT, "the exercise of dominance and privilege suppresses authenticity and mutuality in relationships, limiting and interfering with the formation of growth-fostering relationships." Inherent in the RCT is the notion that systems have the "need to be in connection in order to change, to open up, to shift, to transform..." (Jordan and Hartling, 2002, 8). Using this perspective, I argue that rather than magnifying the differences between cultural relativism and universalism in peace and development studies, we need to focus on opportunities for mutuality, conversation and partnership in addressing the peace, justice and development needs of people in conflict and post conflict settings.

\footnotetext{
${ }^{1}$ Chaos Theory and Restorative Justice. Available at: http://gritsforbreakfast.blogspot.com/2007/06/chaos-theory-
} and-restorative-justice.html [Accessed on 7th July 2007] 


\section{CONCLUDING REMARKS}

From the foregoing discussion, it is quite evident that the boundaries of universalism and cultural relativism in peace and development studies should be conceptualized as points of connection, exchange and growth rather than areas of separation. The theoretical underpinnings of "cosmopolitan localism" proposed by Dietrich and Sützl $(2006,225)$ are very useful in furthering this debate. Cosmopolitan localism seeks to amplify the richness of a place while keeping in mind the rights of a multi-faceted world. It cherishes a particular place, yet at the same time knows about the relativity of all places" Dietrich and Sützl $(2006,225)$.

It is therefore crucial for cultural relativists and universalists to constantly converse, negotiate and creatively engage with each other to contribute to peace and development studies. It also means that in designing strategies to promote peace and development we need to take into account the needs of the place and the space and perceive peace and development as a hybrid rather than a form setting standards that are assumed to be universally applicable in all contexts.

This would contribute to making pragmatic use of the synergetic positive elements in both the place (which is culturally relative) and space (which may have incomplete and impure elements seen to apply to more than one culture at a given point in time and space). It is such an ingenious hybrid which leans towards the profane discourse that will help to reduce impasses between cultural relativism and universalism and instead promote mutual respect and coexistence in the pursuit of peace and development in conflict and post conflict settings.

\section{Acknowledgements}

I want to thank Mr. Ismail Nyanzi Ddumba, Makerere University School of Social Sciences, Uganda for editing my initial drafts. I am grateful to all the students of the International Master in Peace, Conflict and Development Studies of the University of Jaume I (UJI), Castellón, Spain for the motivation they gave me in writing this paper.

\section{References}

[1] Ayoade, J. A. A., (1997), "Time in Yoruba Thoughts," in R.A. Wright (ed) African Philosophy, An Introduction, Washington D.C.: University Press,1984, pp 93-111.

[2] Briggs J., Peat D., Seven Life Lessons of Choas: Spiritual Wisdom from the Science of Change. New York: HarperPerennial, a Divsion of Harper Collins Publishers, 1999.

[3] Bukuluki, P. Negotiating Retributive and Restorative Justice in Conflict Transformation Efforts: A case of Northern Uganda, Münster-Berlin-Hamburg-London-Wien-Zürich: LIT-Verlag, 2010.

[4] Chaos Theory and Restorative Justice, Available at: http://gritsforbreakfast.blogspot.com/2007/06/chaos-theory-and-restorative-justice.html [Accessed on 7th July 2007]

[5] Dietrich W., Sützl W., “A Call for Many Peaces”, in Key Texts of Peace Studies, ed. Dietrich, Echavarria and Koppensteiner, 282-305,Vienna, LIT Verlag, 2006.

[6] Glasersfeld, Ernst von (1989) Constructivism in Education. In: T.Husen and T. Neville Postlethwaite (eds) The International Encyclopedia of Education. Research and Studies, pp. 162-163. Supplementary Volume 1. Oxford: Pergamon Press, 1989. 
[7] Glasersfeld, E Knowing without Metaphysics: Aspects of the Radical Constructivist Position. In: F.Steier (ed.) Research and Reflexivity, pp. 12-29. London: Sage, 1991.

[8] Gyekye, K. An Essay On African Philosophical Thought: The Akan conceptual scheme, Rev. ed. (Philadelphia: Temple University Press, 1995).

[9] Gbadegesin, S. "'Enylyan: The Yoruba Concept of A Person." in The African Philosophy Reader, eds.. P. H. Coetzee and A. P. J. Roux London Routledge, 1998, pp 175.

[10] Helman C., Culture, Health and Illness. Fourth Edition, London: Hodder Arnold, 2007.

[11] Ikwenobe P., Philosophical Perspectives on Communalism and Morality in African Traditions. New York: Lexington Books, 2006.

[12] Jordan, J. V., Hartling, L. M.. New developments in relational-cultural theory. In M. Ballou \& L. S. Brown (Eds.), Rethinking mental health and disorder: Feminist perspectives (pp. 48-70). New York, NY: Guilford Press. 2002.

[13] Kleinman, A.. Concepts and a model for the comparison of medical systems as cultural systems. Soc. Sci. and Med. 12:85-93; 78, 1988.

[14] Kwame G., "The Akan Concept of Pearson International Philosophical Quarterly 18 (1978, 277-287. Reprinted in Africa philosophy: An introduction, ed. Richard A. Wright, New York: University Press of America. 1984

[15] Lübbe, A. (2009). "Us Versus Them: Splitting Dynamics and Turning Points in Ethnopolitical Conflict." Journal of Peace, Conflict and Development 13. Available at: http://www.peacestudiesjournal.org.uk/dl/Issue $\% 2013 \% 20$ Article $\% 2016 \% 20$ final $\% 20 \mathrm{v}$ ersion\%20pdf.pdf. Accessed on $17^{\text {th }}$ September 2012.

[16] Lund, C. Development and Rights: Tempering Universalism and Relativism, 1999. In Christian Lund, Development and rights: Negotiating Justice in Changing Societies, Frank Cass Publishers, Britain, (Ed 1999, 1-8)

[17] Levy, D. Chaos Theory and Strategy: Theory Application and Managerial Implications. Strategic Management Journal, 15 (1994) 167-178.

[18] Miller, J. B. (1976). Toward a New Psychology of Women. Boston: Beacon Press.

[19] Norval A., 'Hybridization': The Im/Purity of the Political. In Sovereignty and Subjectivity, Ed.Edkins, Persram, and Pin-Fat. 99-116. London: Leine Reiner Publishers, 1999.

[20] Sachs W., "One World", in Key Texts of Peace Studies, ed. Dietrich, Echavarria and Koppensteiner, 282-305,Vienna, LIT Verlag 1992. 